\title{
Acroneuria kirchneri Stark \& Kondratieff, 2004 is a synonym of Acroneuria kosztarabi Kondratieff \& Kirchner, 1993 (Plecoptera: Perlidae)
}

\author{
CHRIS J. VERDONE ${ }^{1}$, ERIC J. SOUTH² \& BORIS C. KONDRATIEFF ${ }^{3}$ \\ ${ }^{1}$ North Carolina Department of Environmental Quality, Division of Water Resources, Water Sciences Section, Biological Assessment \\ Branch, Raleigh, North Carolina, 27607, U.S.A. \\ झ"chris.verdone@ncdenr.gov; ㅇttps://orcid.org/0000-0001-8482-0708 \\ ${ }^{2}$ Natural Sciences Division, Lyon College, Batesville, Arkansas, 72501, U.S.A.

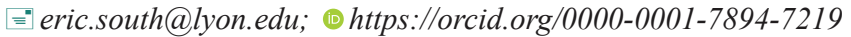 \\ ${ }^{3}$ Department of Bioagricultural Sciences and Pest Management, Colorado State University, Fort Collins, Colorado, 80523, U.S.A.

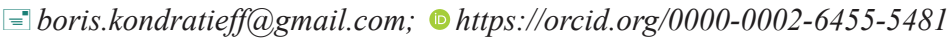

\begin{abstract}
Acroneuria Pictet, 1841 (Plecoptera: Perlidae) is a genus of stoneflies which presently includes 18 summer emerging Nearctic species. Diagnosis of species relies primarily on male aedeagal setal patterns, details of the ovum chorion, and larval dorsal maculations. Several species are morphologically cryptic in one or more life stages. In 2010, an apparently rare species, A. kosztarabi Kondratieff \& Kirchner, 1993, was petitioned for listing under the Endangered Species Act. A status survey conducted in 2016-2017 produced new specimen collections from near the type locality and surrounding areas. Examination of new material and the holotype of A. kirchneri Stark \& Kondratieff, 2004 demonstrates that it is a junior subjective synonym of $A$. kosztarabi. All life stages of $A$. kosztarabi are redescribed using color photographs and scanning electron microscope photomicrographs. Supporting data include maximum likelihood and pairwise genetic distance analyses based on mitochondrial cytochrome c oxidase subunit I fragment data. Acroneuria kosztarabi, previously known only from the type locality, is now reported from six states in the southeastern United States ranging from central North Carolina to western Tennessee and north to northern Virginia and northern Ohio.
\end{abstract}

Key words: Plecoptera, Perlidae, Nearctic, Acroneuria, synonymy

\section{Introduction}

Acroneuria kosztarabi was described by Kondratieff \& Kirchner (1993) from five adults collected from Station Spring Creek located in the anticlinal valley of Burkes Garden, Tazewell County, Virginia. The valley is approximately 13.7 $\mathrm{km}$ long and $6.4 \mathrm{~km}$ wide and is the highest elevation valley in Virginia at $914 \mathrm{~m}$ (Hoffman 1969). No additional records had been reported from Virginia, suggesting that the distribution of the species was restricted to the type locality. Acroneuria kosztarabi was reported from Ohio by DeWalt et al. (2012) and Grubbs et al. (2013), but those records were later examined by CJV and changed to A. kirchneri Stark \& Kondratieff, 2004 based in part on their geographic proximity to known populations in Kentucky and West Virginia.

Adults of A. kosztarabi resemble both A. kirchneri and A. filicis Frison, 1942. Ova can be helpful in delineating Acroneuria species, but morphological characters of ova can be very similar between species (Stark \& Gaufin 1976; Stark 2004; Grubbs et al. 2013). Additionally, little is known regarding intraspecific variation of the chorion. The completely punctate egg chorion of A. kosztarabi is identical to A. kirchneri and A. flinti Stark \& Gaufin, 1976 (Stark 2004).

The apparent rarity of $A$. kosztarabi led to it being petitioned for listing under the Endangered Species Act in 2010 (Center for Biological Diversity 2010). A US Fish and Wildlife Service funded status survey, conducted in 2016-2017, produced new specimens from near the type locality and surrounding areas. Comparison of the holotype of $A$. kosztarabi to newly collected material indicated that the original description of the male aedeagus required revision. Specifically, the basal spinule band on the aedeagus which was originally described as complete 
on the dorsal surface is actually divided. This observation challenged the taxonomic validity of A. kirchneri, deemed novel based in part on this aedeagal character (Stark \& Kondratieff 2004). Herein, we propose that $A$. kirchneri is a junior synonym of $A$. kosztarabi. Supporting evidence includes an amended description of the adult male and female A. kosztarabi, description of the larva, scanning electron microscope (SEM) photomicrographs of the ovum chorion, and analysis of mitochondrial cytochrome c oxidase subunit I (COI) gene fragment sequences.

\section{Methods}

Adult stoneflies were collected using beating sheets, aerial nets, UV light traps and hand-picking from riparian vegetation and substrates. Larvae were collected using a D-frame kicknet or hand-picked as they emerged from stream margins and were immediately preserved in $80-95 \%$ ethanol or reared to adulthood. Adults were held for a period of time in ventilated jars to allow for complete sclerotization. A subset of adult males were prepared alive. The aedeagi were everted using wide tipped forceps, thereafter the specimens were fixed in position by briefly submerging them in near boiling water. Eversion of preserved specimens was achieved using the methods detailed in Verdone \& Kondratieff (2017).

Coordinate data for new material were recorded directly using Topo Maps version 1.16 for iPhone. Additional specimens were examined from the C. P. Gillette Museum of Arthropod Diversity, Colorado State University, Fort Collins, Colorado (CSUIC), North Carolina Division of Water Resources Biological Assessment Branch Collections (NCDWR), Raleigh, North Carolina and the United States National Museum of Natural History, Washington D.C. (NMNH). Specimens used in the molecular analysis not mentioned above were from Big South Fork National River and Recreation Area, Oneida, Tennessee (BISO), Illinois Natural History Survey, Champaign, Illinois (INHS) and Henan Institute of Science and Technology, Xinxiang, China (HIST). Analysis methods of examined specimens are denoted as SEM or DNA in parentheses following specimen repository. Coordinate data for legacy specimen records were gathered using GEOLocate v. 3.22 (Rios \& Bart 2010) and are indicated by "[ ]". Plotting of coordinate data and map measurements were accomplished using ArcMap, ArcGIS 10.8.1. Level III/IV eastern Nearctic ecoregion data for the were obtained from the US Environmental Protection Agency (USEPA 2019) and drainage data were acquired from USGS StreamStats program 4.1.1 (U.S. Geological Survey 2016). Codens for national parks are: BISO, Blue Ridge Parkway (BLRI) and Great Smoky Mountains (GRSM).

Specimens were stack-photographed using a Nikon D2900 mounted on a Wild M5-A. Composite images were assembled using Zerene Stacker version 1.04 (Zerene Systems LLC, Richland, Washington) and subsequently adjusted using Adobe Photoshop version 21.0.3. Ova were either taken from an extruded egg mass or dissected from the female oviduct and cleaned in $80 \%$ ethanol using a fine tipped paint brush and sonicated for 30 seconds to remove tissue adhering to the ovum surface. Ova were air dried and mounted on an aluminum stub using double stick copper tape then sputter coated with gold. Micrographs were taken using a JEOL JSM-6500F Field Emission SEM at the Central Instrument Facility, Imaging Laboratory, Colorado State University, Fort Collins, Colorado and an Amray 1810 SEM, the latter courtesy of Dr. Bill Stark, Mississippi College, Clinton, Mississippi.

Total DNA was extracted from 22 Acroneuria and one Remenus bilobatus (Needham \& Claassen, 1925) using a DNeasy Blood and Tissue Kit (Qiagen Sciences Inc., Valencia, California) following the manufacturer's standard protocols. Samples were processed and sequenced either at the Canadian Centre for DNA Barcoding (CCDB) (Guelph, Canada) or the North Carolina Museum of Natural Sciences (NCMNS) Genomics and Microbiology Research Lab via polymerase chain reaction (PCR) with Sanger technology following the protocol from deWaard et al. (2008). The primer pair LCO1490 and HCO2198 (Folmer et al. 1994) and modified Folmer primers CLepFolF and CLepFolR (Hernández-Triana et al. 2014) were used (at NCMNS and CCDB, respectively) to amplify the barcode region of the COI gene. Additional COI sequences from nine Acroneuria specimens and one Perlinella ephyre (Newman, 1839) were obtained from GenBank (https://www.ncbi.nlm.nih.gov/genbank/). Sequences processed through CCDB/NCMNS and those retrieved from GenBank were aligned using MUSCLE 3.8 (Edgar 2004).

In total, 33 sequences representing five Acroneuria species and two outgroup species (Table 1) were trimmed to a uniform length of 636 nucleotides and analyzed for evolutionary model selection, phylogenetic relatedness, and pairwise genetic distances using MEGA X (Kumar et al. 2018). A maximum likelihood (ML) analysis was performed using the top-ranked Bayesian information criterion (BIC) and Akaike information criterion corrected for sample size (AICc) nucleotide substitution model, the Tamura 3-parameter model with a gamma distribution and a 
proportion of invariable sites $(\mathrm{T} 92+\mathrm{G}+\mathrm{I})$ (Tamura 1992). The ML analysis included all codon positions, non-coding sites, and 1000 bootstrap replicates. Pairwise genetic distances were determined using the Kimura 2-parameter model (K2P) (Kimura 1980) with the pairwise deletion option for ambiguous positions. Sequences are available from GenBank and the Barcode of Life Database (BOLD) (http://www.boldsystem.org; Ratnasingham \& Hebert 2007).

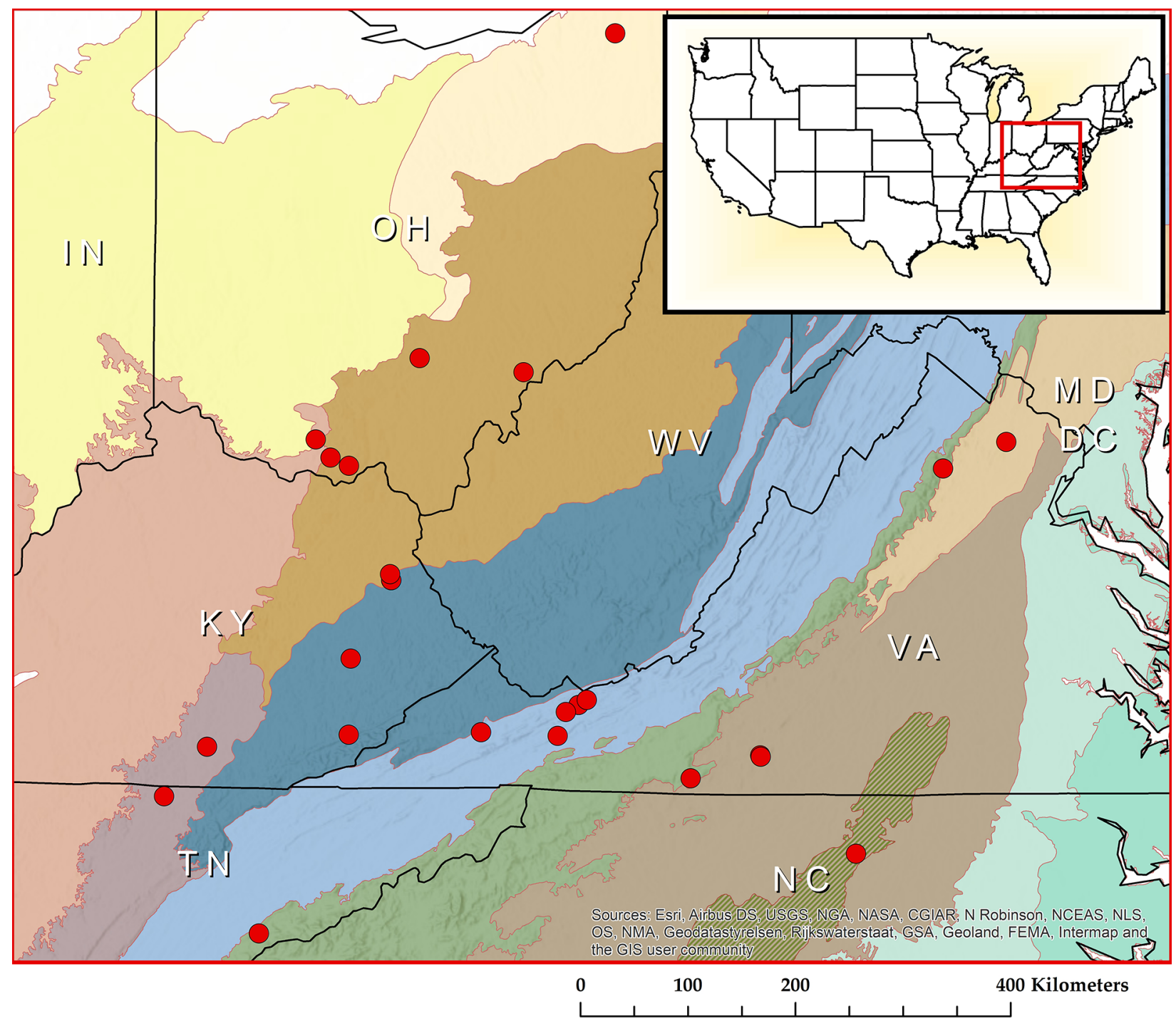

\section{Legend}

- Acroneuria kosztarabi

State Boundaries

\section{Lv III Ecoregions}

\begin{tabular}{|l|l}
\hline Blue Ridge \\
Central Appalachians \\
\hline$\quad$ Eastern Corn Belt Plains \\
\hline$\quad$ Erie Drift Plain \\
\hline Interior Plateau
\end{tabular}

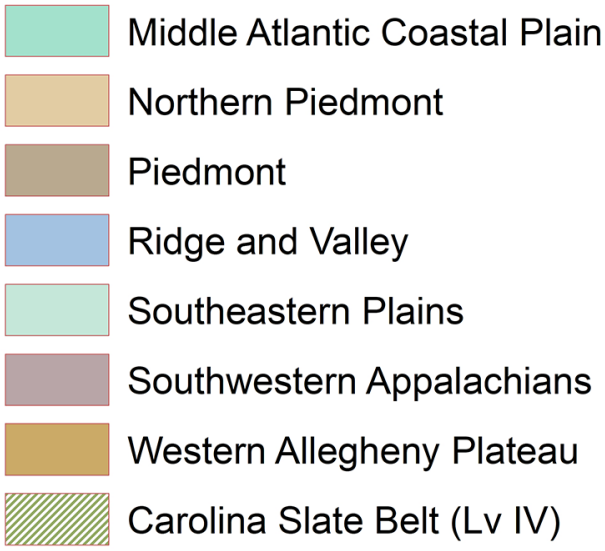

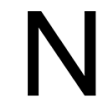

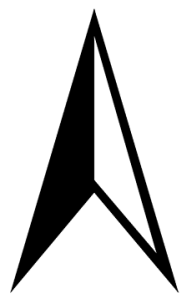

FIGURE 1. Distribution of Acroneuria kosztarabi based on specimens analyzed genetically or with associated ova. 


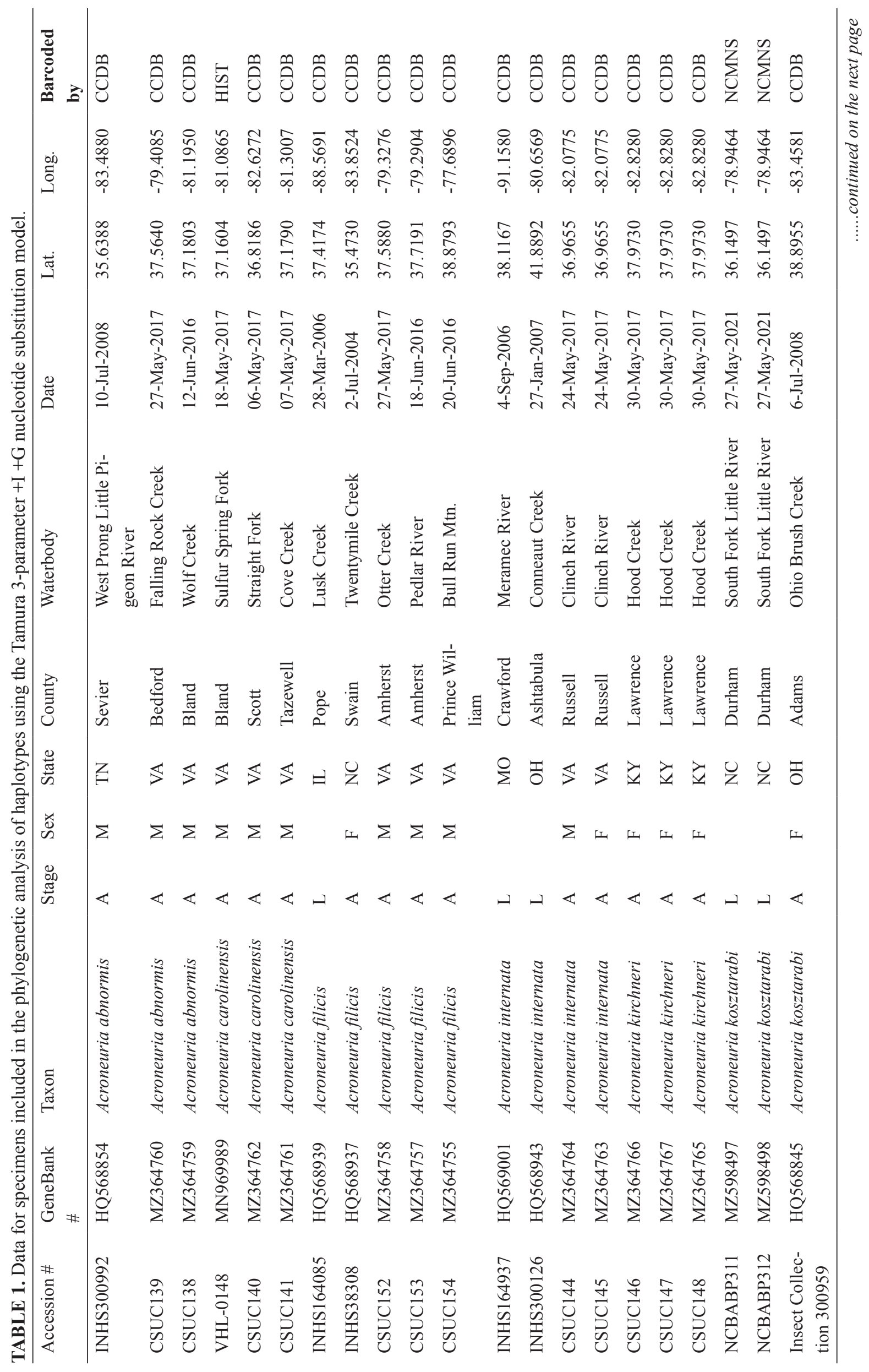




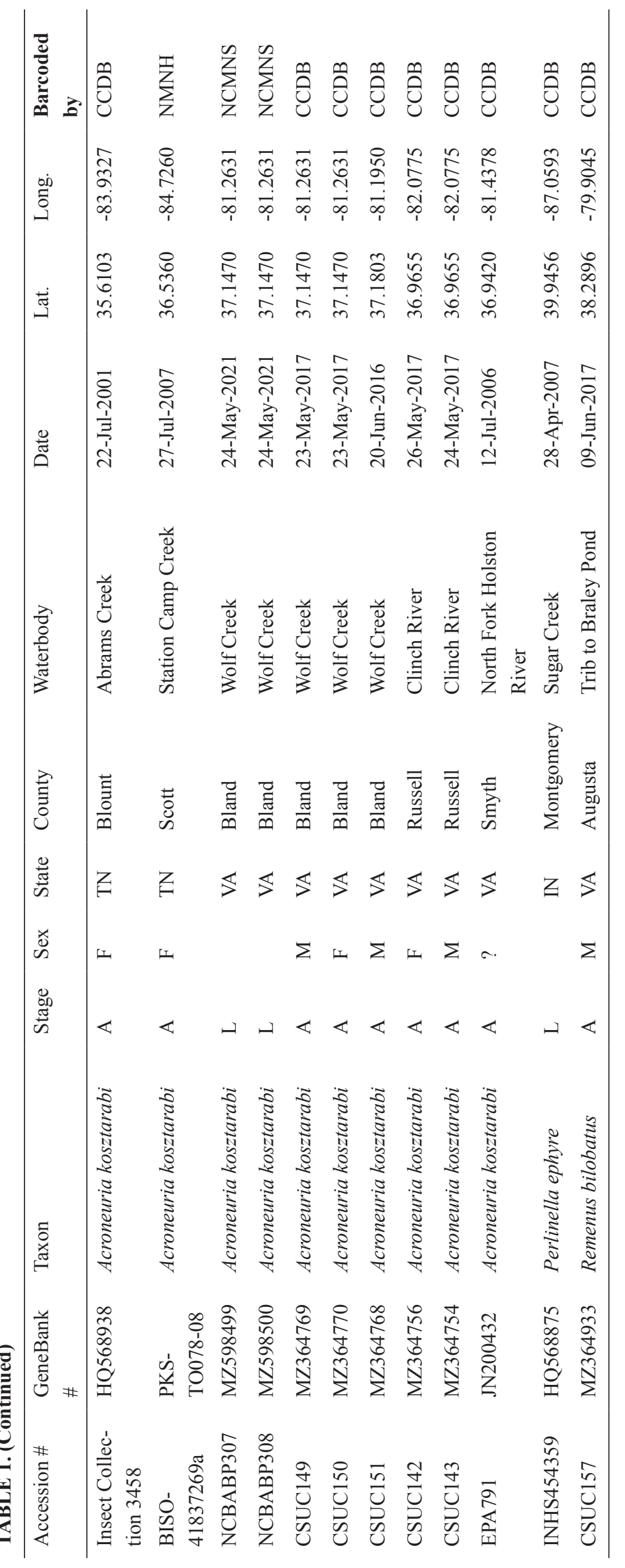




\section{Results}

Acroneuria kosztarabi Kondratieff \& Kirchner, 1993

(Figs. 2-30)

Acroneuria kosztarabi Kondratieff \& Kirchner, 1993: 550. Holotype M: Virginia, Tazewell County, Burkes Garden (NMNH) Acroneuria kosztarabi: Stark 2004: 70

Acroneuria kirchneri Stark \& Kondratieff, 2004: 393. Holotype M: Kentucky, Lawrence County, Hood Creek (NMNH) Syn. n. Acroneuria kirchneri: Stark 2004: 70

Material examined. U.S.A - Kentucky: Breathitt Co., Clemons Fork, Robinson Forest, [37.45513, -83.16545], 17 June 2010, M. Floyd, 1F (CSUIC SEM). Harlan Co., [Isaac Creek], Laurel House parking lot, [36.94842, -83.18258], 12 June 2009, J. Robinson, 1F (CSUIC SEM). Lawrence Co., Hood Creek, 1.5 mi. S of Blaine, [38.01405, -82.83694], 18 May 1994, B.C. Kondratieff, R.F. Kirchner, 2M, 2F (CSUIC paratypes SEM); same data, 2F (CSUIC: paratypes); Hood Creek, Ross Branch Rd. E of Hwy 201, 37.97299, -82.82796, 30 May 2017, C. Verdone, 10F (CSUIC DNA). McCreary Co., Eagle Creek, KY 896, [36.86834, -84.36732], 9 June 2007, M. Floyd, 1F (CSUIC SEM). North Carolina, Durham Co., South Fork Little River, SR 1461, 36.149722, -78.94638, 27 May 2021, C. Verdone, 5L (NCDWR DNA). Ohio: Adams Co., Upper Churn Creek, [Shawnee] State Forest, [38.77761, -83.33452], 15 June 1995, no collector information, 1F (INHS OBS-INHS 6435). Hocking Co., Queer Creek, NE South Bloomingville along Hwy 664, [39.42360, -82.59084], 19 June 1996, H. Sharb, 1F (INHS OBS-INHS 7343). Scioto Co., Mackeltree Run, 8 km NW Friendship at confluence with Lake Roosevelt, [38.72390, -83.18150], 20 June 1999, E. Chapman, 3F (INHS OBS-INHS 3142). Trumbull Co., Mill Creek, $10 \mathrm{~km}$ NE Middlefield at Sweet West Rd. bridge, [41.48940, -80.95670], 4 July 1994, V. Fazion, 1F (INHS OBS-INHS 3170). Washington Co., Little West Branch, CR3 bridge, E. Decaturville, [39.33224, -81.72322], 18 June 1996, T. Troutner, 1F (INHS OBS-INHS 6869). Virginia: Bedford Co., Rye Cove Creek, Rte 815, 4 mi. NW of Stuart, [36.65750, -80.32664], 5 July 2008, R.L. Hoffman, 2F (CSUIC SEM). Bland Co., Wolf Creek, Rte 614, Stephen Levitt Property, 37.14702, $-81.26314,4$ June 2016, C. Verdone, B.C. Kondratieff, 1F (CSUIC SEM); same location, 5 June 2016, C. Verdone, B.C. Kondratieff, 1M, 2F (CSUIC); same location, 6 June 2016, C. Verdone, B.C. Kondratieff, 1F (CSUIC); same location, 8 June 2016, C. Verdone, B.C. Kondratieff, 2F (CSUIC); same location, 23 May 2017, C. Verdone, 1M, 1F (CSUIC DNA); same location, 25 May 2017, C. Verdone, D. Fuller, 1M 3E (CSUIC); same location 27 May 2017, C. Verdone, D. Fuller, 3M, 16 E (CSUIC); same location, 28 May 2017, C. Verdone, 7M, 3F, 5E (CSUIC); same location, 24 May 2021, C. Verdone, 9L (NCDWR DNA); Wolf Creek, Rte 614, Wolf Creek Picnic Area, 37.18026, $-81.19496,8$ June 2016, C. Verdone, B.C. Kondratieff, 2M, 1F (CSUIC); same location, 12 June 2016, C. Verdone, B.C. Kondratieff, 2M, 1 F (CSUIC); same location, 20 June 2016, C. Verdone, 2M, 1 F (CSUIC DNA). Franklin Co., Grassy Fork, Rte 619, [36.81097, -79.74516], 2 June 2000, R.L. Hoffman, 1F (CSUIC SEM); Henry Co., Machine Creek, at Rt. 619 Crossing, [36.801867, -79.741136], 12 July 2009, R.L. Hoffman, 1F (CSUIC SEM). Patrick Co., Rye Cove Creek, rt. 815, 4 mi. NW of Stuart, [36.65749, -80.32663], 5 July 2008, R.L. Hoffman, 1F (CSUIC SEM). Prince William Co., Catharpin Creek, Jackson Hollow Campground, [38.87930, -77.68958], 30 May-15 June 2015, D.R. Smith 1F (CSUIC SEM). Cattlets Branch, Bull Run Mtns, [38.83218, -77.70473], 30 July 1998, C. S. Hobson, 1F (CSUIC SEM). Rappahannock Co., Covington River, VA Hwy 614, 3 mi W of Washington, 38.70549, -78.21945, 10 July 1989, R.L. Hoffman, 1F (CSUIC SEM); Russell Co., Clinch River, Rte 798 SE of Rte 645 nr. Nash Ford, 36.96550, -82.07750, 24 May 2017, C. Verdone, 1M (CSUIC DNA); same location, 27 May 2017, C. Verdone, D. Fuller, 1F (CSUIC DNA). Tazewell Co., Burkes Garden, Flatwoods, [NO GPS], 5 July 1987, V.M. Dalton, 1F (CSUIC paratype); Station Spring Creek, Burkes Garden, [37.10065, -81.36992], 17 August 1987, UV, V.M. Dalton, 1M (NMNH Holotype). same data, 1F (CSUIC SEM).

Additional records from BOLD and GenBank. Acroneuria kosztarabi: Ohio: Adams Co., Ohio Brush Creek, 7 km SW, Peebles at Hull Rd. Public Access, 38.89550, -83.45810, 6 July 2008, R.E DeWalt, 1F (INHS Insect Collection 300959, HQ568845). Tennessee: Blount Co., Abrams Creek, Abrams Creek Campground, GRSM, 35.6103, -83.9327, 22 July 2001, B.D. Heinold, A. Zimmerman, 1F (INHS Insect Collection 3458, HQ568938). Scott Co., Station Camp Creek, downstream Charit Creek Lodge, Big South Fork National River Recreation Area, 36.53600, -84.72600, 27 July 2007, M. Geraghty, C.R. Parker, 1F (BISO-41837269a, PKSTO078-08). Virginia: Smyth Co., North Fork Holston River, Nebo, Rte 622, [36.94202, -81.43780], 12 July 2006 O.S. Flint, Adult (sex unknown) (NMNH, JN200432). 


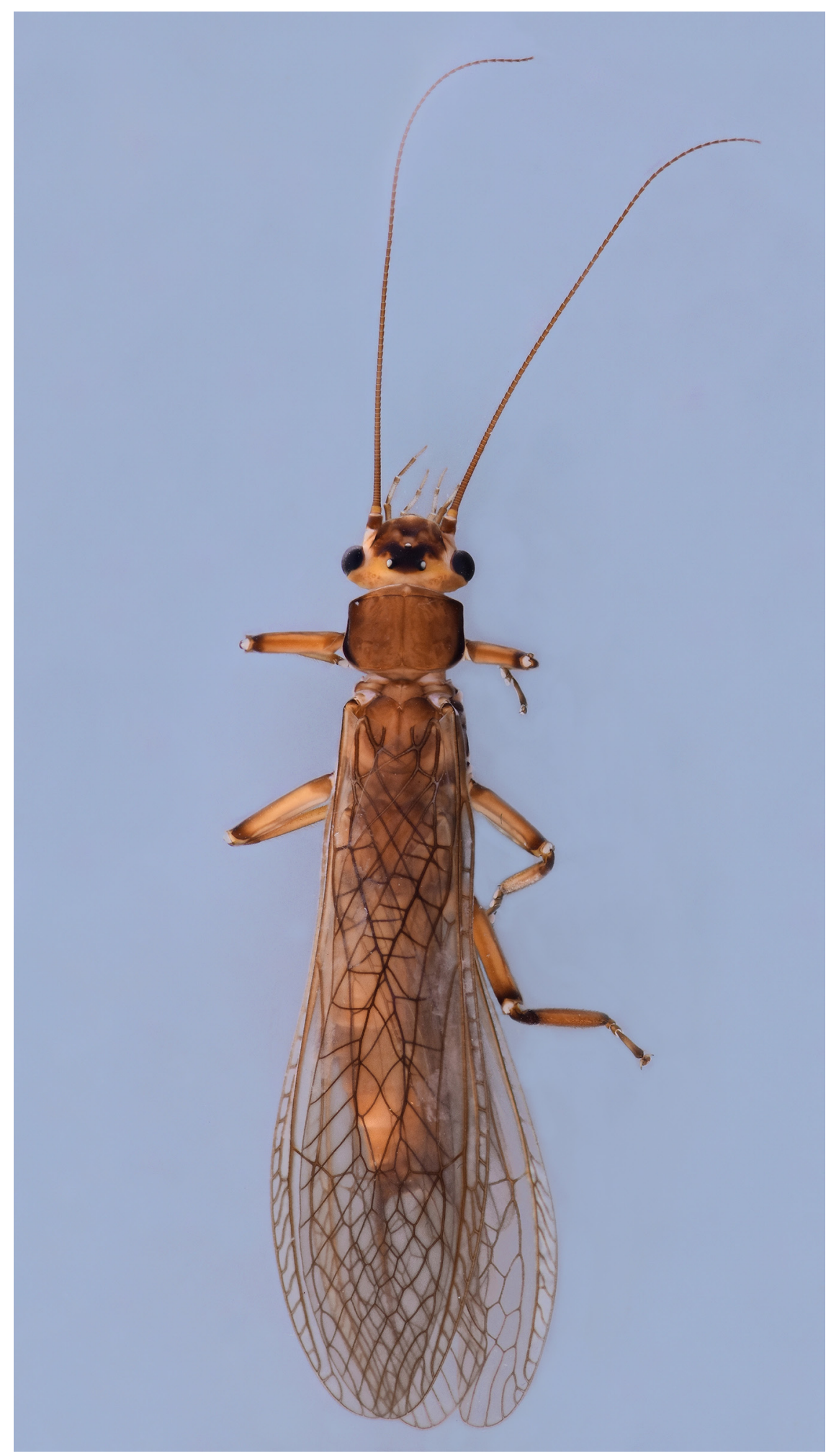

FIGURE 2. Acroneuria kosztarabi, adult male, habitus, dorsal, Wolf Creek, Bland County, Virginia.

Additional material examined. Virginia: Bedford Co., Falling Rock Creek, BLRI, 37.56400, -79.40850, 27 May 2017, C. Verdone, D. Fuller, 1M (CSUIC DNA). Bland Co., Wolf Creek, Rte 614, Wolf Creek Picnic Area, 37.18030, -81.19500, 12 June 2016, C. Verdone, B.C, Kondratieff, 1M (CSUIC DNA). Virginia: Scott Co., Straight Fork, Rte 619, Devils Fork Loop Trail, 36.81860, -82.62720, 06 May 2017, C. Verdone, B.C. Kondratieff, S. Roble, 1M (CSUIC DNA). Tazewell Co., Cove Creek, Rte 622, 37.17900, -81.30070, 07 May 2017, C. Verdone, B.C. Kondratieff, S. Roble, 1M (CSUIC DNA). Virginia: Amherst Co., Otter Creek, Otter Creek Overlook, BLRI, 
37.58802, -79.32760, 27 May 2017, C. Verdone, D. Fuller, 1M, 3N, 1E (CSUIC DNA); Otter Creek, MP 56.7, BLRI, [37.62370, -79.33459], 17-18 July 2007, C.R. Parker, 7F, 1E (CSUIC DNA); Pedlar River, FR 315, above Panther Falls, 37.71912, -79.29043, 18 June 2016, C. Verdone, 1M, 1F (CSUIC DNA). Prince Williams Co., Catharpin Creek, Jackson Hollow Campground, Bull Run M.C., 38.87930, -77.68958, 3-20 June 2016, D.R. Smith, 5M (CSUIC DNA). Virginia: Russell Co., Clinch River, Rte 798 SE of Rte 645 Nr. Nash Ford, 36.96550, -82.07750, 24 May 2017, C. Verdone, 1M, 1F (CSUIC DNA).

Distribution. U.S.A. - KY, OH, NC, TN, VA, WV*. (Fig. 1) *Specimens from West Virginia reported by Stark $\&$ Kondratieff (2004) were not examined. While it is likely those records are valid, they were not included in the distribution map.
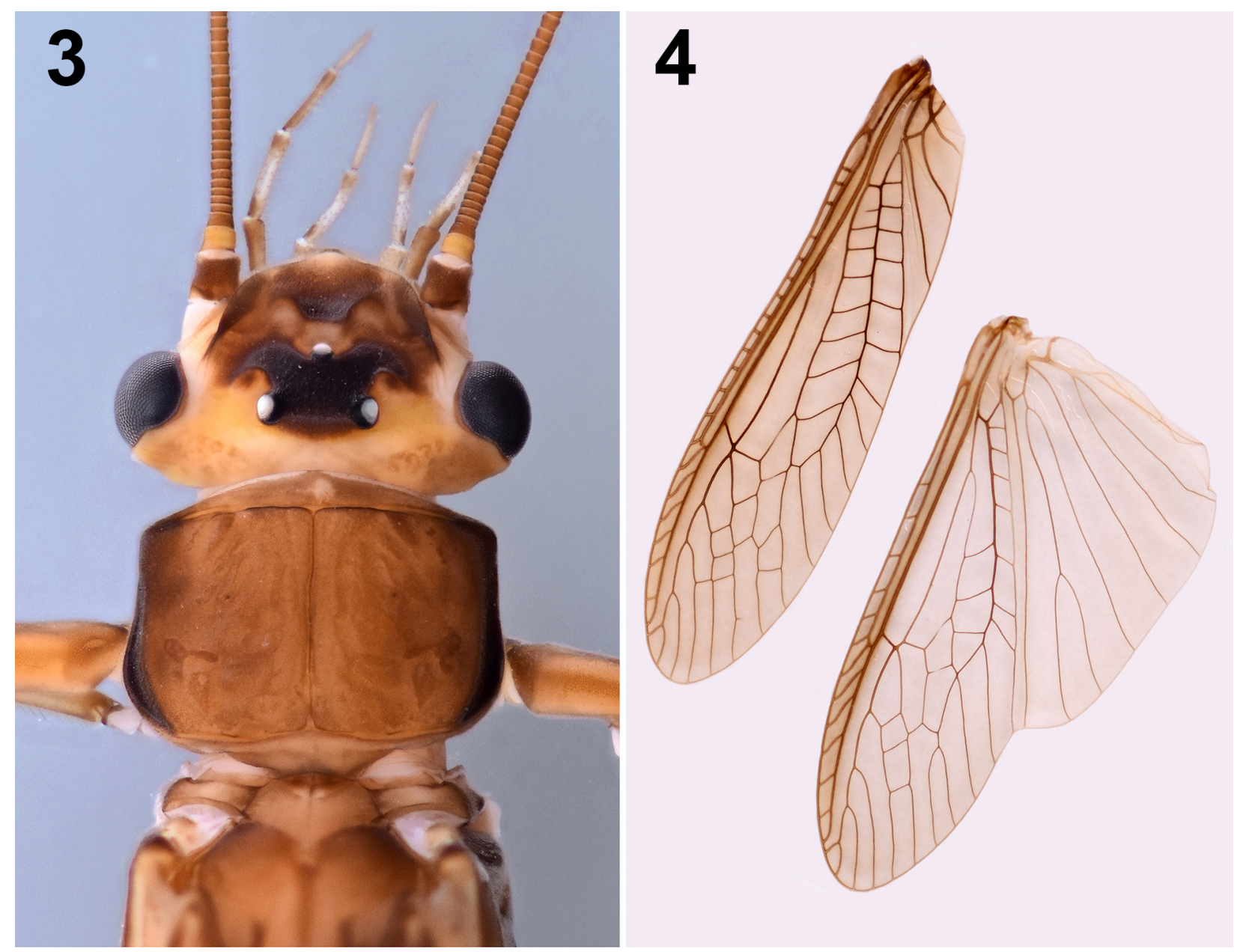

FIGURES 3-4. Acroneuria kosztarabi, adult male, Wolf Creek, Bland County, Virginia. 3. Head and pronotum, dorsal. 4. Forewings and hindwings.

Male. (Fig. 2). Macropterous; forewing length, 21.3-23.2 mm; body length, 18.8-20.0 mm $(\mathrm{n}=5)$. General body color yellow-brown. Dorsum of head yellow-brown (Fig. 3); interocellular area enclosed with dark brown pigment; dark pigment extends anterolaterally and recurves posteriorly to a tapered point; pale sinuous M-line anterior to the median ocellus (Fig. 3); frons medium brown; pale bands extend anteriorly from lateral margins of M-line; lateral margins of frons medium brown; epicranial suture extending well beyond the lateral ocelli; postocular rugose spots present (Fig. 3). Antennal scape medium brown, pedicel yellow-brown, flagellum medium brown. Pronotum medium brown with irregular rugosities; posterolateral margins darkened (Fig. 3). Mesonotum and metanotum light to medium brown (Fig. 3); wings hyaline with medium brown veins (Fig. 4). Femora yellow-brown with darkened proximal and distal margins connected by a darkened dorsal stripe (Fig. 2). Tibia yellow brown with darkened proximal margin. Tarsi medium brown. Abdominal terga pale yellow to yellow, darkening laterally; lateral margins medium brown; abdominal sterna yellow; terga 9-10 with paired submedial patches of sensilla basiconica (Fig. 5). Hammer on tergum 9 rounded and moderately sclerotized (Fig. 6). Paraprocts slender, apices acutely pointed, 
deflected ventrad at apex (Fig. 5). Aedeagus with an apical lobe, ventral lobe and ventral quadrangular lobe; apical lobe broadly rounded basally, tapering to a narrow medial projection (Figs. 5-8); dorsum of apical lobe with a broad, golden-brown chevron-shaped setal patch basally (Figs. 5, 7); apical patch either entire or narrowly divided; basal setal patch situated posterior to basal lobe (Figs. 5, 7); basal patch narrowly divided dorsomedially (Figs. 5, 7); consisting of golden brown setae that encircle the aedeagus; ventral patch of setae extends ventrad and laterad to base of apical lobe (Fig. 6); setae tends to be darker and thicker in the mesal area appearing as a stalk (Fig. 6); basal lobe with a few fine setae dorsally and prominent quadrangular lobe ventrally (Fig. 8).

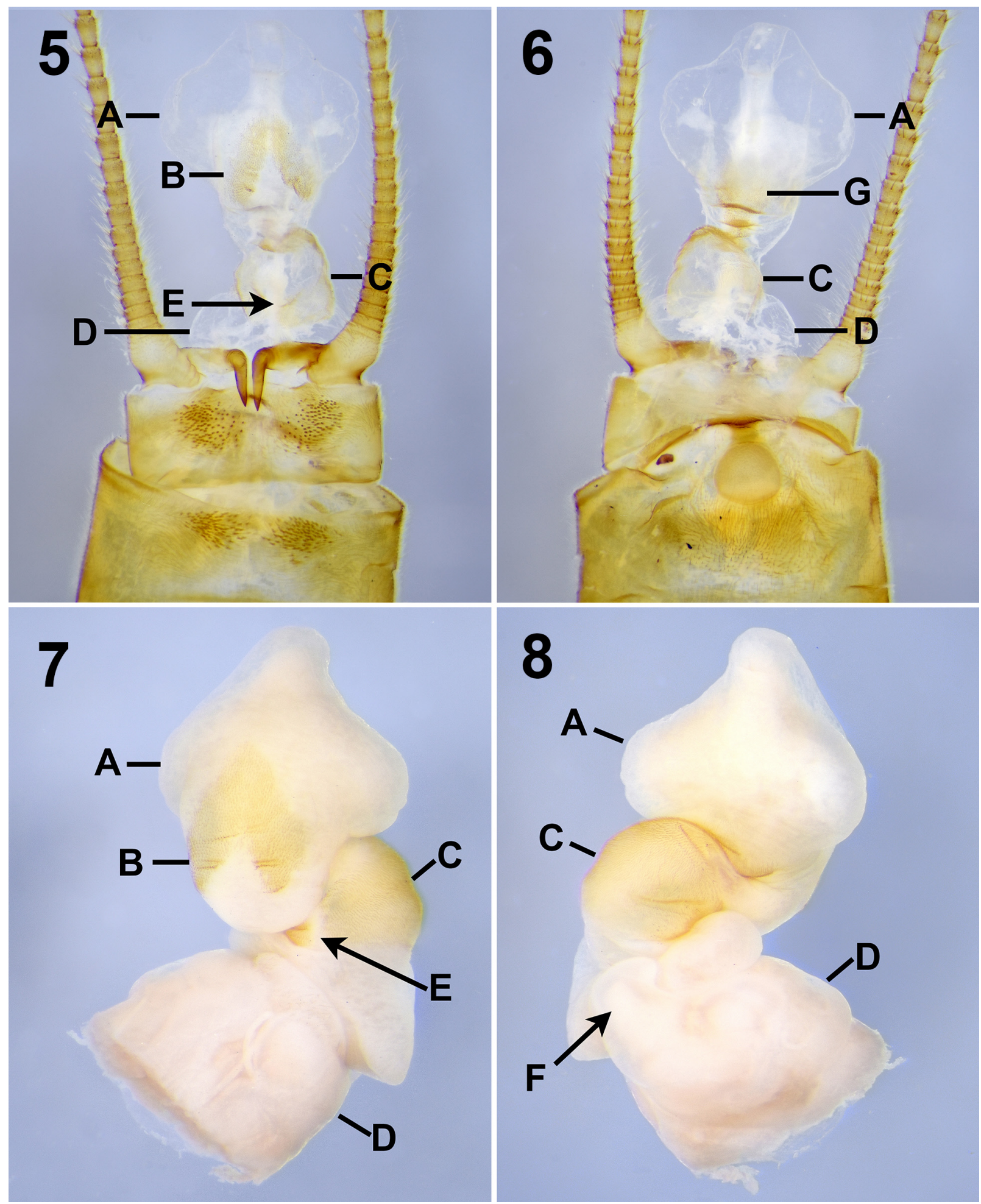

FIGURES 5-8. Acroneuria kosztarabi, male, Wolf Creek, Bland County, Virginia. A. Apical lobe. B. Apical setal patch. C. Basal setal patch. D. Basal lobe. E. Dorsomedial division of basal setal patch. F. Quadrangular ventral lobe. G. Ventral setal patch. 5. Terminalia, dorsal. 6. Terminalia, ventral. 7. Aedeagus, dorsal. 8. Aedeagus, ventral. 


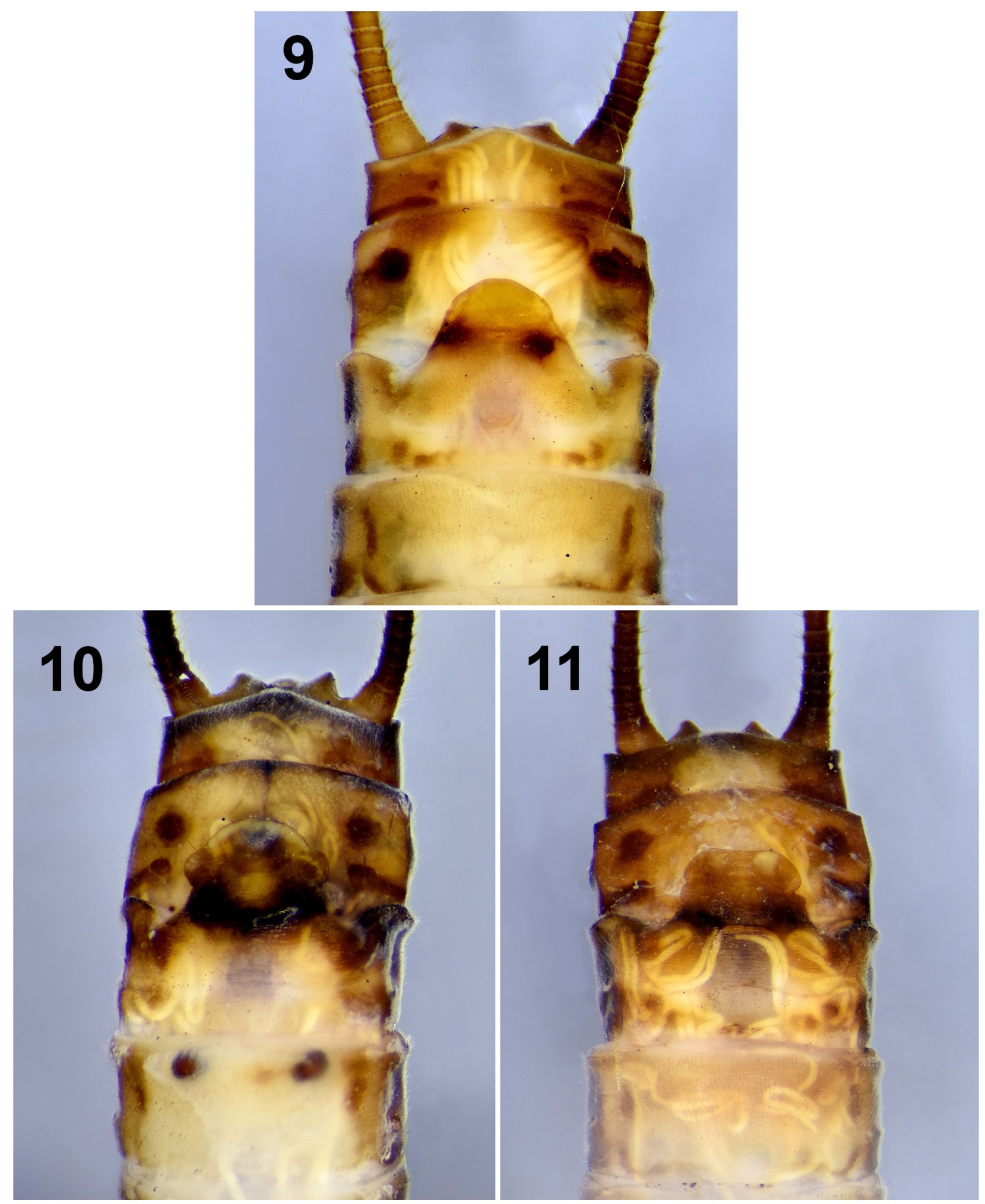

FIGURES 9-11. Acroneuria kosztarabi, female abdominal sterna 8-10, ventral. 9. Wolf Creek, Bland County, Virginia. 10-11. Hood Creek, Lawrence County, Kentucky.

Female. Macropterous; forewing length, 26.5-29.5 mm $(\mathrm{n}=5)$. Body length, 21.9-24.1 mm $(\mathrm{n}=5)$. General color and morphology similar to the male. Subgenital plate extending 1/3-1/2 the length of tergum 9 (Figs. 9-11); with or without lateral constrictions; with only minor or without medial emargination; occasionally asymmetrical (Figs. 9-11).

Ovum. (Figs. 12-23). Length 509-564 $\mu$ m; width $370-393 \mu \mathrm{m}(\mathrm{n}=6)$. Outline strawberry-shaped. Cross- 
section circular. Collar covered with a removable membranous cap. Chorion completely pitted with irregularly sized punctations. Micropyles situated near apical 1/4 (Fig. 13).
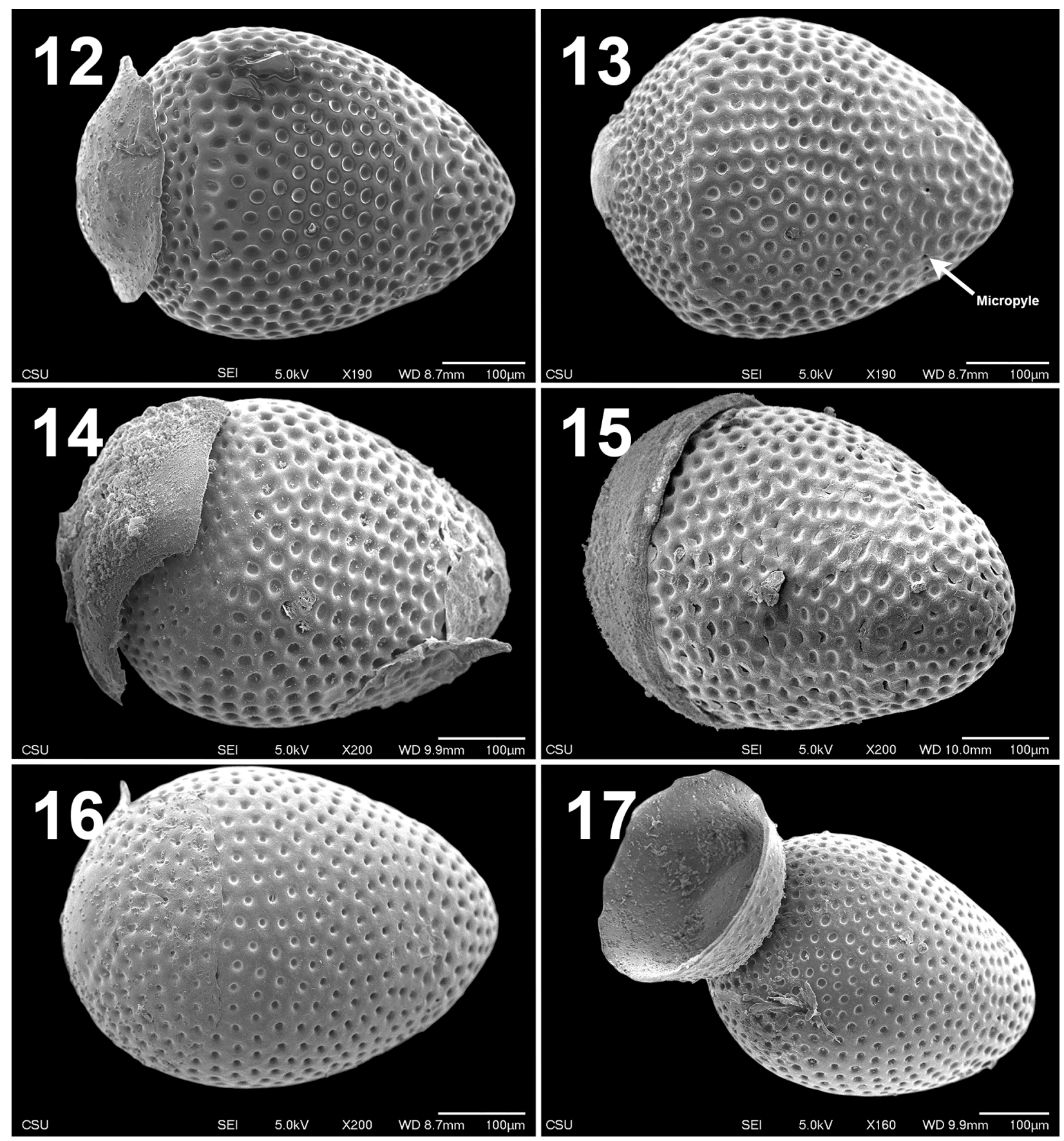

FIGURES 12-17. Acroneuria kosztarabi, ovum. 12. Station Spring Creek, Tazewell County, Virginia. 13. Wolf Creek, Bland County, Virginia. 14. Grassy Fork, Franklin County, Virginia. 15. Machine Creek, Henry County, Virginia. 16-17. Hood Creek, Lawrence County, Kentucky.

Larva. (Fig. 24). Mature body length $20.0-27.0 \mathrm{~mm},(\mathrm{n}=6)$. General body color pale yellow with contrasting brown markings. Dorsum of head pale yellow with brown pigment extending from the epicranial suture to frontoclypeus; broad pale-yellow M-line anterior to median ocellus completely enclosed by brown pigment; posterior and distal margins of lateral ocelli open to occipital pale area; frontoclypeus pale yellow; labrum medium brown with a small triangular pale area anteromedially (Fig. 25). Antennal scape pale yellow, with or without brown mottling; flagellum pale yellow. Postocular area with a ridge of 25-35 stout setae. Lateral margins of occiput with a non-linear grouping of 10-15 stout setae. Mandibles with 5 teeth and a dense brush of marginal setae; submarginal setae on both venter and dorsum (Fig. 26). Lacinia bidentate (Fig. 27); subapical tooth $4 / 5$ the length of apical 
tooth; marginal setae receding evenly towards base from subapical tooth; length of marginal setae decreases evenly towards base; basal marginal setae short and bifurcate (Fig. 27 inset). Maxillary palp 5-segmented and longer than lacinia; galea slightly shorter than lacinia (Fig. 27). Pronotum with contrasting pigment; irregular network of brown pigment medially; anterior and posterior margins with short stout setae; lateral margins of disc pale and without regularly spaced, short stout setae (Fig. 25). Mesonotum and metanotum with contrasting pigment and irregularly spaced hair-like setae; distal and proximal margins of wing pads with short stout setae. Mesosternum Y-arm with a long stem, arms reaching anterior corners of furcal pits. Femora, tibia and tarsi mostly pale yellow; anterior face of femora with brown markings becoming more prominent distally; femora and tibia with long dorsal fringes of silky setae (Fig. 28). Abdominal terga medium brown anteriorly, pale posteriorly; brown bands wavy, typically narrowed medially and covering $1 / 2-1 / 3$ of respective terga (Fig. 29A), but may extend to posterior margin of tergum (Fig. $30 \mathrm{~A}$ ); posterior margins with tergum 10 variable, but typically with brown anterior band and thin brown posterior band. Dorsum of abdomen with scattered stout setae; posterior margins with a single row of stout setae. Abdominal sterna 1-9 mostly pale with darkened anterolateral margins becoming progressively darker on each segment; sternum 10 entirely brown, or with a pale medial area. Anal gills present; number of filaments variable, arising from a single origin (Fig. 29B) or up to 10 separate origins (Fig. 30B) on the dorsal face of each paraproct; gill origins covered with small spicules and bearing several stout setae. (Fig. 30b); cerci encircled with a fringe of silky setae arising from among spine whorls; most prominent on the proximal side; typically reduced or absent ventrally (Fig. 24).

Diagnosis. Adults of $A$. kosztarabi are conspecific with A. kirchneri and they are morphologically indistinguishable from A. filicis. Presently, ova are necessary to morphologically distinguish A. kosztarabi from A. filicis. The ovum of $A$. kosztarabi is easily separated from A. filicis by the completely pitted chorionic surface. In contrast, the ovum of A. filicis is typically only pitted apically beyond the micropyles (Stark 2004, fig. 7.78), but may be pitted up to approximately $50 \%$ of the ovum length (S. A. Grubbs \& R. E. DeWalt unpublished data). Larvae of $A$. kosztarabi are similar to A. filicis and A. frisoni Stark \& Brown, 1991 and cannot be distinguished using available keys (Stark 2017).

Molecular Analysis. The ML analysis of COI barcode sequences also supported the synonymy of the two species (Fig. 31). All haplotypes from Wolf Creek, Virginia representing A. kosztarabi and Hood Creek, Kentucky (A. kirchneri), along with specimens from Clinch River, Virginia and South Fork Little River, North Carolina were recovered collectively as a single clade with $100 \%$ bootstrap support (BS) (Fig. 31). The remaining haplotypes were recovered as monophyletic groups according to respective species with high nodal support [(BS $=100 \%$ for $A$. abnormis (Newman, 1838), A. carolinensis (Banks, 1905), A. internata (Walker, 1852); BS =99\% for A. filicis (Fig. 31)]. With the exception of $A$. kosztarabi and A. kirchneri, all minimum interspecific K2P distances were greater than maximum intraspecific K2P distances (Table 2). The sequence for one A. kosztarabi specimen (PKSTO078, Scott County, Tennessee) was identical to that of an A. kirchneri specimen (MZ364767, Lawrence County, Kentucky).

TABLE 2. Maximum intraspecific and minimum interspecific (nearest neighbor) Kimura 2-parameter distance values for COI within Acroneuria. $\mathrm{N}=$ number of specimens.

\begin{tabular}{lllll}
\hline Species & $\mathrm{N}$ & $\begin{array}{l}\text { Maximum intraspecific } \\
\text { distance (\%) }\end{array}$ & Nearest neighbor & $\begin{array}{l}\text { Nearest neighbor } \\
\text { distance }(\%)\end{array}$ \\
\hline A. abnormis & 3 & 2.4 & A. carolinensis & 16.0 \\
A. carolinensis & 3 & 1.1 & A. abnormis & 16.0 \\
A. filicis & 5 & 0.8 & A. kosztarabi & 7.6 \\
A. internata & 4 & 1.4 & A. filicis & 16.5 \\
A. kirchneri & 3 & 0.2 & A. kosztarabi & 0 \\
A. kosztarabi & 13 & 1.6 & A. kirchneri & 0 \\
\hline
\end{tabular}

Biological notes. Acroneuria kosztarabi occurs in at least nine EPA level III Ecoregions throughout the eastern Nearctic region (USEPA 2019) (Fig. 1). Within these areas adults have been collected near streams of various sizes from small headwaters such as Cattlets Branch, Prince William County, Virginia (drainage area $=3.3 \mathrm{~km}^{2}$ ) to rather large drainages such as the Clinch River, Russell County, Virginia $\left(\right.$ drainage area $=1251 \mathrm{~km}^{2}$ ). Based on the presence of multiple age classes, the population in Wolf Creek, Bland County, Virginia appears to have a semivoltine (two year) life cycle, similar to other Acroneuria species with which A. kosztarabi is sympatric. Schmidt \& Tarter (1985) 
documented a two-year life cycle for A. carolinensis in West Virginia. Populations of $A$. abnormis (Newman, 1838) in Michigan have also been documented as requiring two years (Bottorff \& Knight 1987). Conversely, A. frisoni, which is sympatric with $A$. kosztarabi in the western part of its range has been documented as having a univoltine life cycle in second-order stream in northern Oklahoma (Ernst \& Stewart 1985).
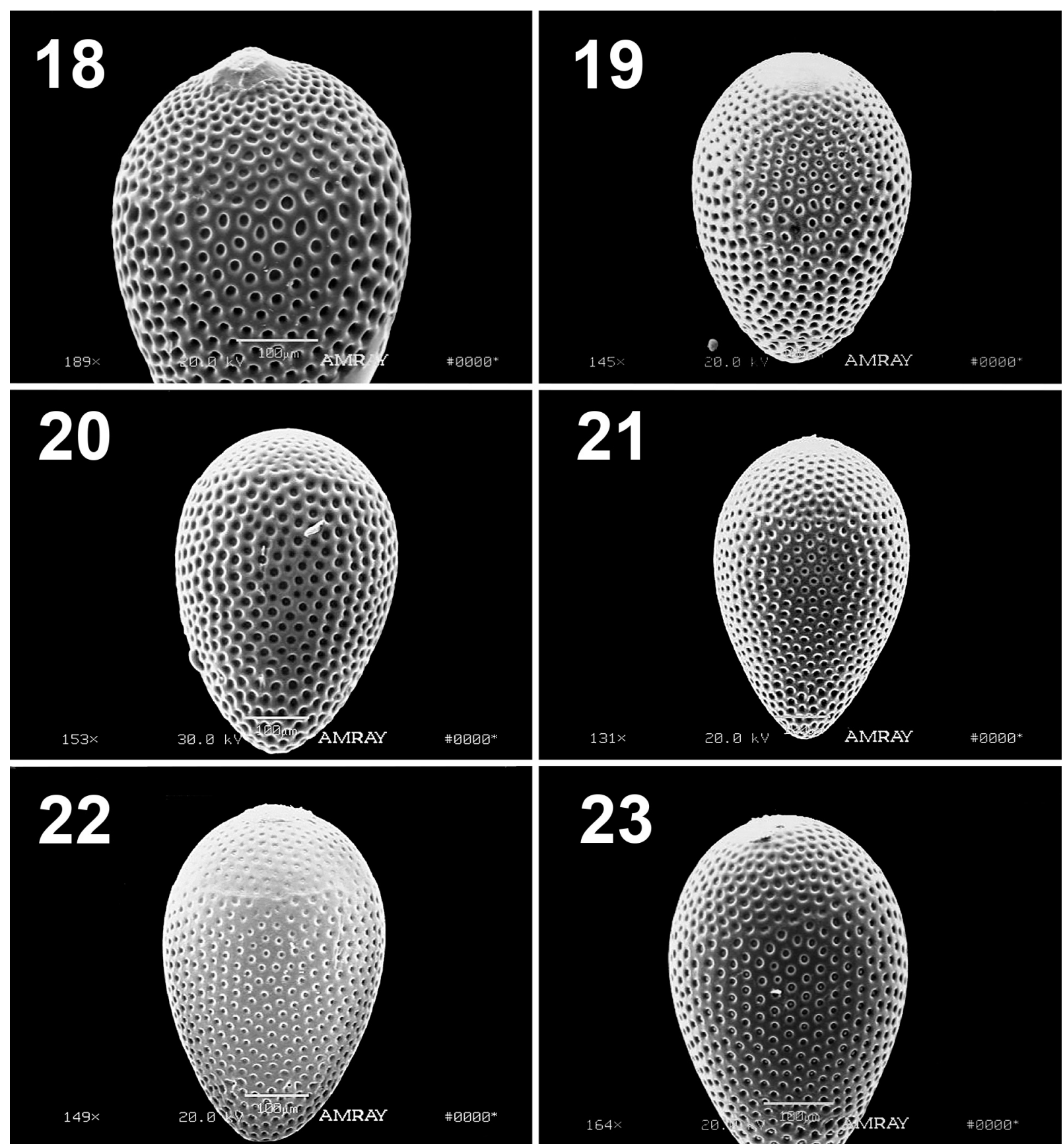

FIGURES 18-23. Acroneuria kosztarabi, ovum. 18. Wolf Creek, Bland County, Virginia. 19. Eagle Creek, McCreary County, Kentucky. 20. Clemons Fork, Breathitt County, Kentucky. 21. Isaac Creek, Harlan Co., Kentucky. 22. Cattlets Branch, Prince William County, Virginia. 23. Covington River, Rappahannock County, Virginia.

Preferred larval habitat of $A$. kosztarabi is apparently areas of lower velocity. Larvae were found among other known run/pool dwellers including Stenacron interpunctatum (Say, 1839), Leucrocuta spp., Psilotreta spp. and Neophylax spp. Numerous benthic samples taken from riffles produced many A. abnormis, but failed to produce any individuals of $A$. kosztarabi. The vast majority of emergent larvae and adults collected from Wolf Creek, Bland County, Virginia, were collected adjacent to pools and runs on either concrete structures or riparian vegetation. Similarly, larvae collected from South Fork Little River, Durham County, North Carolina were collected from depositional areas. 


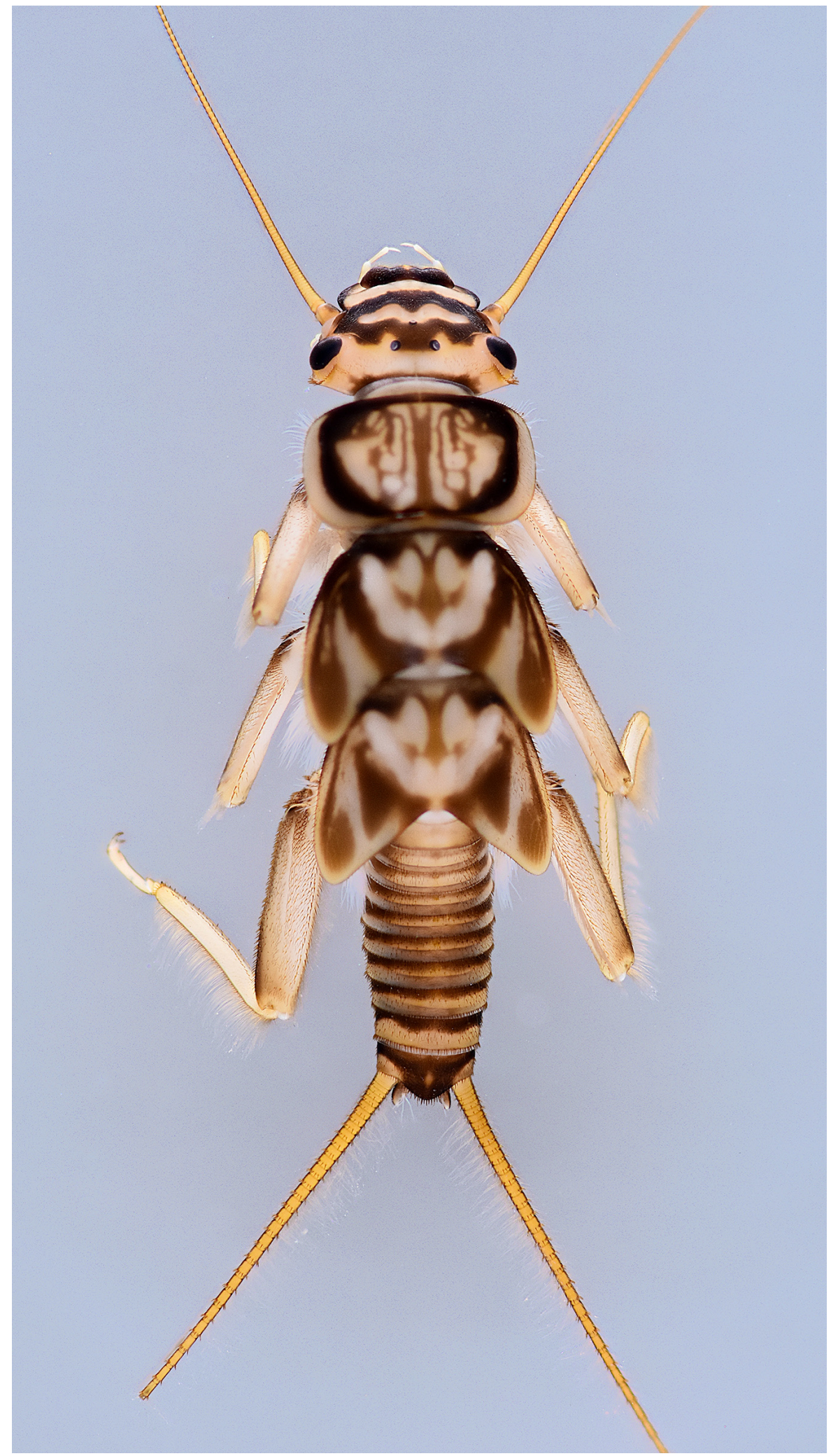

FIGURE 24. Acroneuria kosztarabi, larval habitus, dorsal, Wolf Creek, Bland County, Virginia.

Larvae of $A$. kosztarabi were observed emerging at Wolf Creek from a bridge pool on the evening of 28 May 2017, where emergence apparently began after dusk. The first emergent larva was seen atop the adjacent concrete bridge at 10:30 pm. Emergence continued until approximately 5:30 am, with peak activity occurring between 10:30 $\mathrm{pm}$ and 12:00 am. Larvae typically crawled to the bridge ceiling before beginning ecdysis, which lasted between 5 and 13 minutes. This is perhaps the most vulnerable time for $A$. kosztarabi as they are fully immobilized. Large 
Dolomedes tenebrosus Hentz, 1831 (dark fishing spiders) were observed feeding on emergent larvae. Following ecdysis, some individuals remained still until fully sclerotized, while others resumed crawling towards a terrestrial refugia.
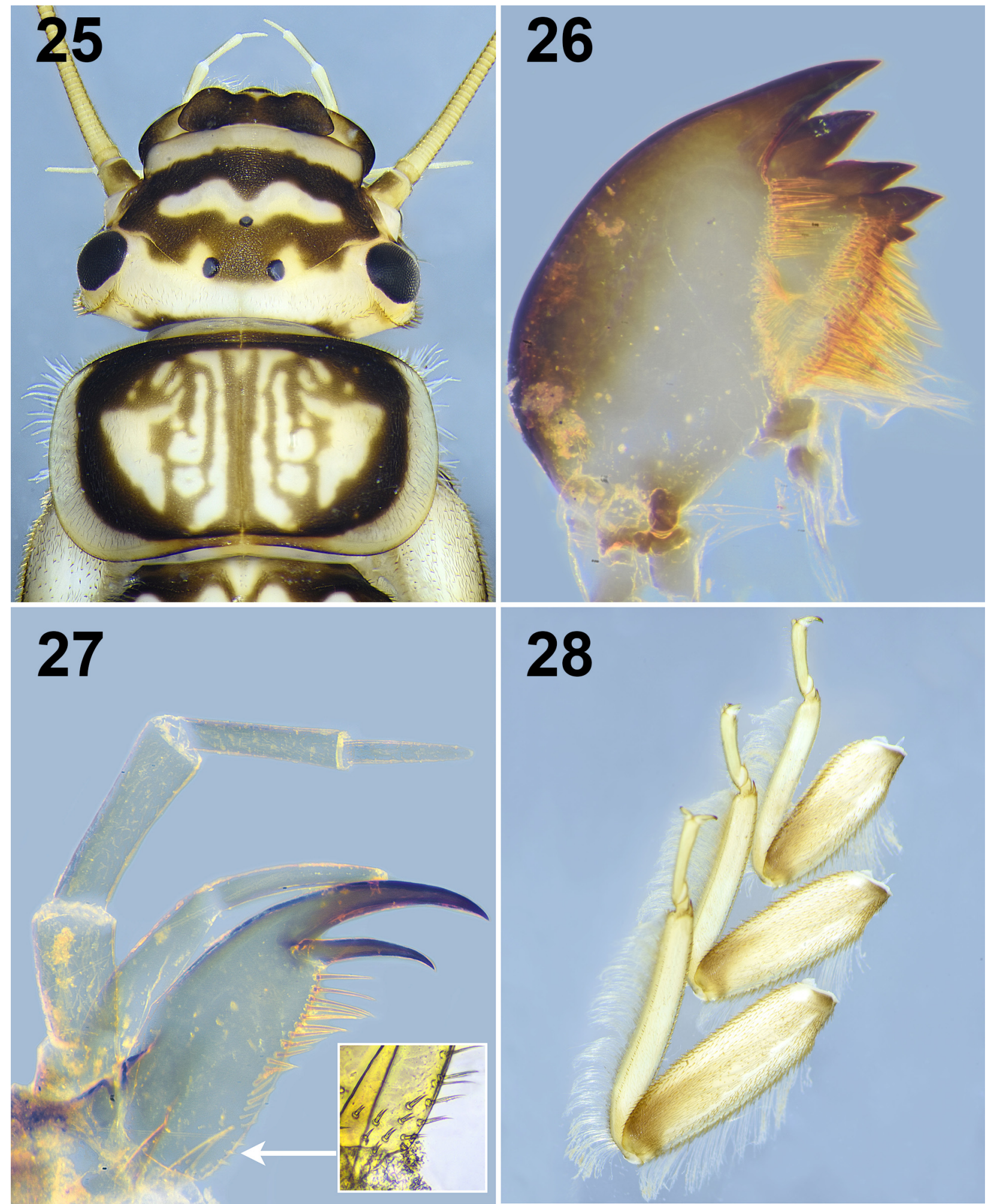

FIGURES 25-28. Acroneuria kosztarabi, larva, Wolf Creek, Bland County, Virginia. 25. Head and pronotum, dorsal. 26. Right mandible. 27. Right lacinia (inset, bifurcate marginal setae) 28. Fore- mid- and hind-legs, anterior face. 


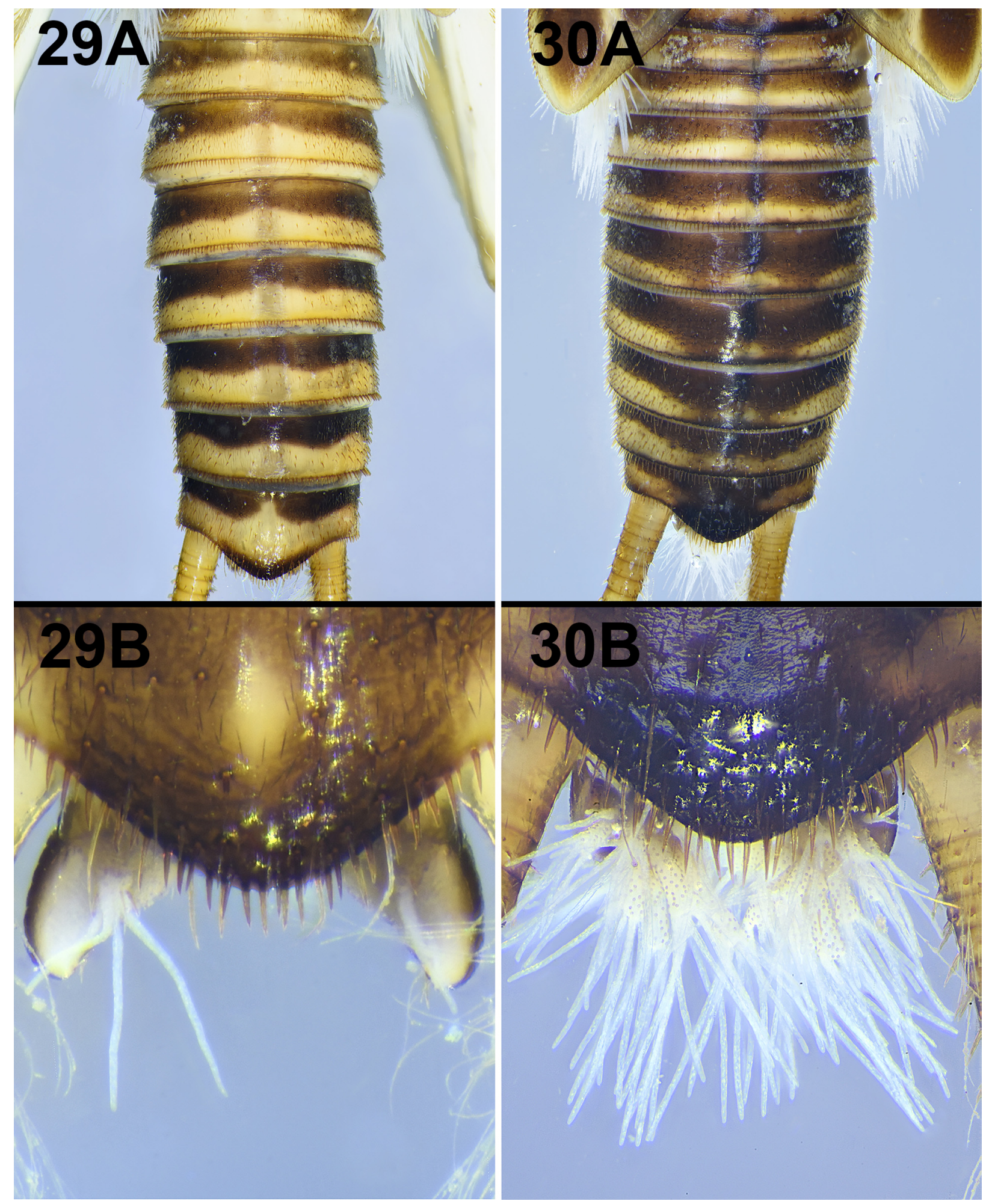

FIGURES 29-30. Acroneuria kosztarabi, larva, dorsal, (A) abdomen, (B) anal gills. 29. Wolf Creek, Bland County, Virginia. 30. South Fork Little River, Durham County, North Carolina.

Based on the examined material, emergence begins in late May. The exact date likely fluctuates annually based on environmental conditions such as air and water temperature. Adults have been collected as late as 17 August from Station Spring Creek, Tazewell County, Virginia. Late emergence of taxa from this location is thought to be in response to the stenothermic conditions of the spring. Type material of Isoperla major Nelson \& Kondratieff, 1983 was collected from near this location as late as 7 September (Nelson \& Kondratieff 1983); notably we collected this species on 7 May 2017 from a spring tributary to Cove Creek, Tazewell County, Virginia. 


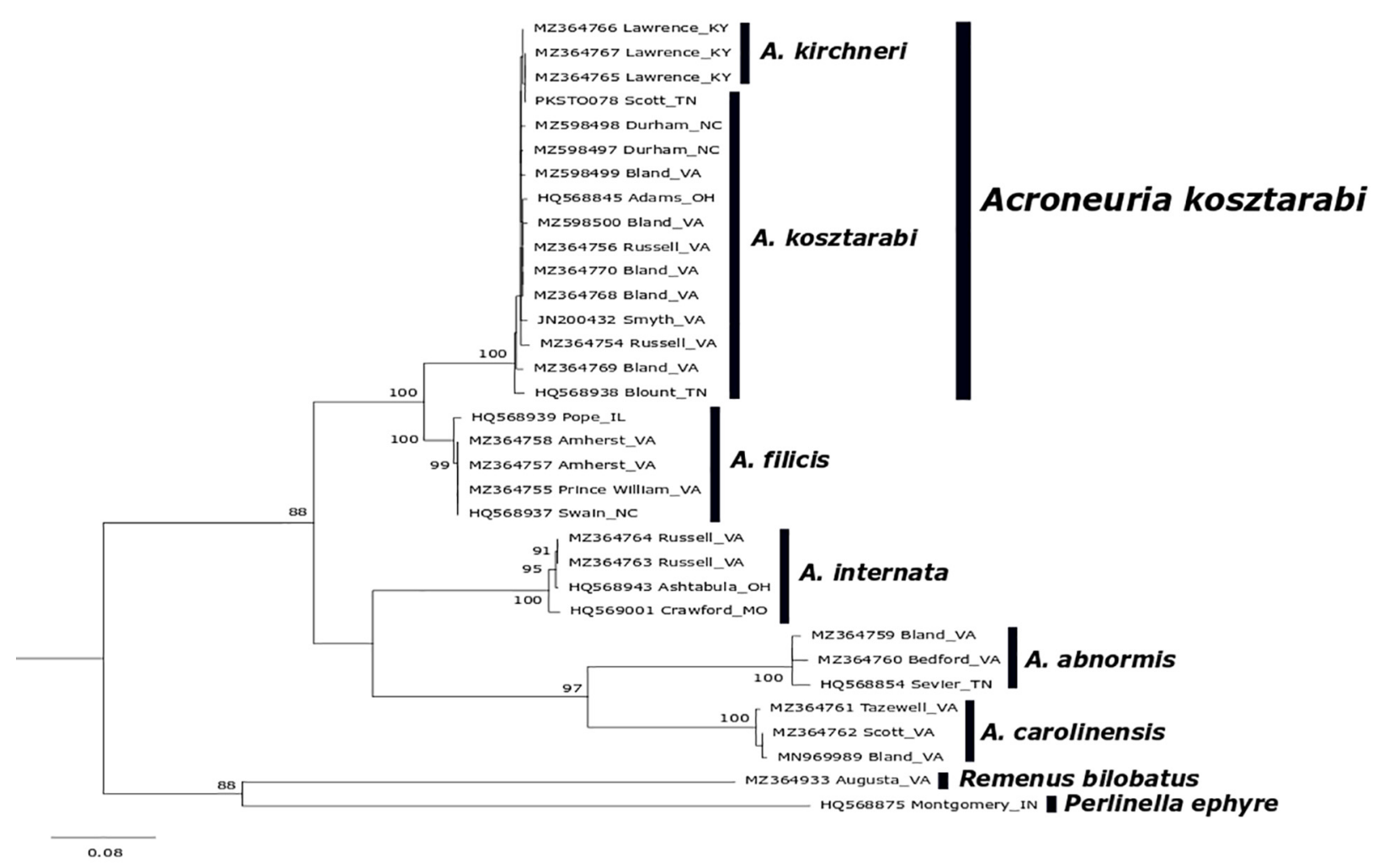

FIGURE 31. Maximum Likelihood phylogenetic analysis of 31 Acroneuria haplotypes using the Tamura 3-parameter $+\mathrm{I}+\mathrm{G}$ nucleotide substitution model. GenBank accession numbers along with collection county and state are listed with corresponding haplotypes. Outgroup taxa include Perlinella ephyre and Remenus bilobatus. Bootstrap support values $(>70 \%)$ from 1,000 replicates are displayed at nodes. Scale bar indicates estimated number of nucleotide substitutions per site.

Discussion. Despite being among the more conspicuous stoneflies in eastern North America, Nearctic Acroneuria remains a taxonomic morass. The genus has bewildered prominent plecopterologists for well over a century resulting in 14 Nearctic synonymies (DeWalt et. al 2021). Of the current 17 Nearctic species, five lack larval descriptions and for those that have been described, larval diagnosis relies primarily on highly variable dorsal maculations. Additionally, subtle variations of the ovum chorion and aedeagal setal patterns currently used to distinguish adults, may not be suitable to separate closely related species. Given the history of synonymy and sometimes difficult specimen preparation, we believe the taxonomy of Nearctic Acroneuria could benefit greatly from a comprehensive molecular review, which could promote and bolster future conservation decisions.

\section{Acknowledgements}

Bambi Teague, National Park Service, Asheville, North Carolina is thanked for granting the following permit: Blue Ridge Parkway, BLRI-2016-SCI-0010. Bill Stark, Mississippi College, Clinton, Mississippi is thanked for providing SEM images of Acroneuria ova. Kim Vanderpool, formerly of Colorado State University, Fort Collins, Colorado is also thanked for her assistance with ova SEM. Thanks are extended to Steve Beaty and Victor Holland, North Carolina Department of Environmental Quality, Raleigh, North Carolina for their thoughtful reviews of the manuscript. Finally, we thank Bronwyn Williams, North Carolina Museum of Natural Sciences, Raleigh, North Carolina for her part in sequencing specimens used in the molecular analysis. 


\section{References}

Bottorff, R.L. \& Knight, A.W. (1987) Ectosymbiosis between Nanocladius downesi (Diptera: Chironomidae) and Acroneuria abnormis (Plecoptera: Perlidae) in a Michigan stream, USA. Entomologia Generalis, 12, 97-113. https://doi.org/10.1127/entom.gen/12/1987/97

Center for Biological Diversity (2010) Petition to list 404 aquatic, riparian and wetland species from the southeastern United States as threatened or endangered under the Endangered Species Act. 1145 pp. Available from: https://www.regulations. gov/document/FWS-R4-ES-2011-0049-0003 (accessed 19 December 2021)

DeWalt, R.E., Cao, Y., Tweddale, T., Grubbs, S.A., Hinz, L., Pessino, M. \& Robinson, J.L. (2012) Ohio USA stoneflies (Insecta, Plecoptera): species richness estimation, distribution of functional niche traits, drainage affiliations, and relationships to other states. ZooKeys, 178, 1-26. https://doi.org/10.3897/zookeys.178.2616

DeWalt, R.E., Hopkins, H., Maehr, M.D., Neu-Becker U. \& Stueber, G. (2021) Plecoptera Species File Online. Version 5.0/5.0. Available from: http://Plecoptera.SpeciesFile.org/ (accessed 23 August 2021)

deWaard, J.R., Ivanova, N.V., Hajibabaei, M. \& Hebert, P.D.N. (2008) Assembling DNA Barcodes: Analytical Protocols. In: Martin, C.C. (ed.), Methods in Molecular Biology: Environmental Genetics, Humana Press Inc., Totowa, New Jersey, pp. $275-283$. https://doi.org/10.1007/978-1-59745-548-0_15

Edgar, R.C. (2004) MUSCLE: a multiple sequence alignment method with reduced time and space complexity. $B M C$ Bioinformatics, 5 (1), 1-19. https://doi.org/10.1186/1471-2105-5-113

Ernst, M.R. \& Stewart, K.W. (1985) Emergence patterns and an assessment of collecting methods for adult stoneflies (Plecoptera) in an Ozark foothills stream. Canadian Journal of Zoology, 63 (12), 2962-2968. https://doi.org/10.1139/z85-444

Folmer, O., Black, M., Hoeh, W., Lutz, R. \& Vrijenhoek, R. (1994) DNA primers for amplification of mitochondrial cytochrome c oxidase subunit I from diverse metazoan invertebrates. Molecular Marine Biology and Biotechnology, 3, $294-299$. [https://www.mbari.org/wp-content/uploads/2016/01/Folmer_94MMBB.pdf ]

Grubbs, S.A., Pessino, M. \& DeWalt, R.E. (2013) Distribution patterns of Ohio stoneflies, with an emphasis on rare and uncommon species. Journal of Insect Science, 13, 72, 1-17. https://doi.org/10.1673/031.013.7201

Hernández-Triana, L.M., Prosser, S.W., Rodríguez-Perez, M.A., Chaverri, L.G., Hebert, P.D.N. \& Gregory, T.R. (2014) Recovery of DNA barcodes from blackfly museum specimens (Diptera: Simuliidae) using primer sets that target a variety of sequence lengths. Molecular Ecology Resources, 14 (3), 508-518. https://doi.org/10.1111/1755-0998.12208

Hoffman, R.L. (1969) The insects of Virginia. No. 1. Part II. In: The biotic regions of Virginia. Research Davison Bulletin. Vol. 48. Virginia Polytechnic Institute and State University, Blacksburg, Virginia, pp. 23-62. [https://www.vmnh.net/content/ vmnh/uploads/PDFs/research_and_collections/the_insects_of_virginia/the_insects_of_virginia_no_1.pdf]

Kimura, M. (1980) A simple method for estimating evolutionary rate of base substitutions through comparative studies of nucleotide sequences. Journal of Molecular Evolution, 16, 111-120. https://doi.org/10.1007/BF01731581

Kondratieff, B.C. \& Kirchner, R.F. (1993) A new species of Acroneuria from Virginia (Plecoptera: Perlidae). Journal of the New York Entomological Society, 101 (4), 550-554. [https://www.jstor.org/stable/25010038]

Kumar, S., Stecher, G., Li, M., Knyaz, C. \& Tamura, K. (2018) MEGA X: Molecular Evolutionary Genetics Analysis across computing platforms. Molecular Biology and Evolution, 35, 1547-1549. https://doi.org/10.1093/molbev/msy096

Nelson, C.H. \& Kondratieff, B.C. (1983) Isoperla major, a new species of eastern Nearctic Isoperlinae (Plecoptera: Perlodidae). Annals of the Entomological Society of America, 76 (2), 270-273 https://doi.org/10.1093/aesa/76.2.270

Ratnasingham, S. \& Hebert, P.D.N. (2007) BOLD: The Barcode of Life Data System (www.barcodinglife.org). Molecular Ecology Notes, 7, 355-364. https://doi.org/10.1111/j.1471-8286.2007.01678.x

Rios, N.E. \& Bart, H.L. (2010) GEOLocate. Version 3.22. Computer Software. Tulane University Museum of Natural History, Belle Chasse, Louisiana. Available from: http:/www.geo-locate.org/web/WebGeoref.aspx/ (accessed 2 March 2021)

Schmidt, D.A. \& Tarter, D.C. (1985) Life history and ecology of Acroneuria carolinensis (Banks) in Panther Creek, Nicholas County, West Virginia (Plecoptera: Perlidae). Psyche, 92 (4), 393-406. https://doi.org/10.1155/1985/85093

Stark, B.P. (2004) Perlidae-(The Stones). In: Stark, B.P. \& Armitage, B.J. (Eds.), The stoneflies (Plecoptera) of eastern North America. Volume II. Chloroperlidae, Perlidae, and Perlodidae. Ohio Biological Survey Bulletin. New Series 14. Ohio Biological Society, Columbus, Ohio, pp. 61-148.

Stark, B.P. (2017) Plecoptera. In: Morse, J.C., McCafferty, W.P., Stark, B.P. \& Jacobus, L.M. (Eds.), Larvae of the Southeastern USA mayfly, stonefly, and caddisfly species. Biota of South Carolina. Vol. 9. Clemson University Public Service Publishing, 
Clemson University, Clemson, South Carolina, pp. 161-247.

Stark, B.P. \& Kondratieff, B.C. (2004) Acroneuria kirchneri (Plecoptera: Perlidae), a new species from eastern North America. Annals of the Entomological Society of America, 97 (3), 393-396. https://doi.org/10.1603/0013-8746(2004)097[0393:AKPPAN]2.0.CO;2

Stark, B.P. \& Gaufin, A.R. (1976) The Nearctic species of Acroneuria (Plecoptera: Perlidae). Journal of the Kansas Entomological Society, 49 (2), 221-253. [https://www.jstor.org/stable/25082817]

Tamura, K. (1992) Estimation of the number of nucleotide substitutions when there are strong transition-transversion and G+ C-content biases. Molecular Biology and Evolution, 9 (4), 678-687. https://doi.org/10.1093/oxfordjournals.molbev.a040752

U.S. Environmental Protection Agency [USEPA] (20190 Level III and IV ecoregions of the continental United States. US Environmental Protection Agency. Available from: https:/www.epa.gov/eco-research/level-iii-and-iv-ecoregionscontinental-united-states (accessed 4 August 2021)

U.S. Geological Survey. 2016. The StreamStats program. Version 4.1.1. Available from: http://streamstats.usgs.gov/ (accessed 4 August 2021)

Verdone, C.J. \& Kondratieff, B.C. (2017) A new species of Isoperla Banks (Plecoptera: Perlodidae) from the southern Appalachians, with notes on the I. montana group. Illiesia, 13 (12), 111-126. [http://illiesia.speciesfile.org/papers/Illiesia1312.pdf] 